\title{
Studi Investigasi Longsor di Desa Kalikuning, Kecamatan Tulakan, Kabupaten Pacitan
}

\author{
Tatas $^{1}$, Machsus ${ }^{2}$, Amien Widodo ${ }^{3}$ \\ 1,2,3. Pusat Studi Kebumian dan Bencana (PSKB) ITS \\ email:tatas@ce.its.ac.id;machsus@ce.its.ac.id;amien@ce.its.ac.id
}

\begin{abstract}
ABSTRAK
Desa Kalikuning, Kecamatan Tulakan, Kabupaten Pacitan merupakan daerah yang mengalami longsor pada tanggal 2 J anuari 2011. Longsor tersebut tepatnya terjadi di Dusun Sono. Letak Desa Kalikuning berada di sebelah timur laut Kota Pacitan. Posisi astronomis Dusun Sono ada pada kisaran koordinat UTM 524522 m Timur; 9101831 m Selatan. Longsor terjadi pada daerah yang memiliki kemiringan topografi. Peristiwa tanah longsor atau dikenal sebagai gerakan massa tanah, batuan atau kombinasinya yang sering terjadi pada lereng alam maupun lereng buatan. Investigasi lapangan dilakukan dengan cara menelusuri retakan tanah dan amblesannya sebagai gejala awal dari longsoran selanjutnya. Pencatatan lokasi retakan berisi tentang koordinat astronomisnya yang diperoleh dari hasil rekaman Global Potitioning Sistem (GPS). Pencatatan koordinat dapat menggunakan sistem yaitu sistem koordinat Universal Transverse Mecator (UTM). Potensi longsor yang lebih besar diperkirakan akan terjadi di Dusun Sono, Desa Kalikuning, Kecamatan Tulakan, Kabupaten Pacitan dengan luasan longsor diperkirakan mencapai 250.000 meter persegi (horisontal). Apabila longsor tersebut terjadi, maka akan menimpa sekitar $47 \mathrm{KK}$ atau 266 jiwa, serta fasilitas umum seperti sekolah dan jalan juga permukiman warga tersebut.
\end{abstract}

Kata Kunci: bencana alam, longsor, Pacitan.

\section{PENDAHULUAN}

Desa Kalikuning, Kecamatan Tulakan, Kabupaten Pacitan merupakan daerah yang mengalami longsor pada tanggal 2 Januari 2011. Longsor tersebut tepatnya terjadi di Dusun Sono. Letak Desa Kalikuning berada di sebelah timur laut Kota Pacitan. Posisi astronomis Dusun Sono ada pada kisaran koordinat UTM 524522 m Timur; $9101831 \mathrm{~m}$ Selatan. Dusun Sono tersebut dapat ditempuh melalui perjalanan darat antara 12 jam dari pusat pemerintahan, Kecamatan Pacitan, Kabupaten Pacitan. Jarak horisontal antara Kecamatan Pacitan dengan Dusun Sono, Desa Kalikuning, Kecamatan Tulakan adalah sekitar $16 \mathrm{Km}$ (Tatas, 2011)[4].

Longsor terjadi pada daerah yang memiliki kemiringan topografi. Peristiwa tanah longsor atau dikenal sebagai gerakan massa tanah, batuan atau kombinasinya yang sering terjadi pada lereng alam maupun lereng buatan. Sebenarnya peristiwa tanah longsor merupakan fenomena alam, yaitu alam mencari keseimbangan baru akibat adanya gangguan atau faktor yang mempengaruhinya dan menyebabkan terjadinya pengurangan kuat geser serta peningkatan tegangan geser tanah. Selain kondisi topografi yang miring, biasanya juga ada pemicu lain yang mengakibatkan suatu tanah mengalami longsor. Pemicu tersebut dapat berupa air hujan dan gempa bumi (Priyono, 2008)[2].

Kontribusi pengurangan kuat geser tanah pada lereng alam yang mengalami longsor disebabkan oleh faktor yang dapat berasal dari alam itu sendiri. Hal ini erat kaitannya dengan kondisi geologi yaitu jenis dan tekstur (komposisi) tanah pembentuk lereng, yang sangat berpengaruh terhadap terjadinya Iongsoran. Kondisi geologi tersebut dapat berupa sensivitas sifatsifat tanah lempung, adanya lapisan tanah shale, 
loose, pasir lepas, dan bahan organik (Suryolelono, 2002)[1].

Pasca terjadinya longsor di Desa Kalikuning tersebut, Pusat Studi Kebumian dan Bencana (PSKB) Institut Teknologi Sepuluh Nopember (ITS) membentuk tim investigasi untuk memantau kondisi lapangan tempat terjadinya longsor. Bekerjasama dengan Dinas Energi dan Sumber Daya Mineral Provinsi Jawa Timur serta Badan Penanggulangan Bencana Daerah (BPBD) J awa Timur, Tim PSKB ITS melakukan survey lapangan terkait bencana tersebut.

Tujuan dilakukannya studi investigasi longsor yang berlokasi di Desa Kalikuning, Kecamatan Tulakan, Kabupaten Pacitan (lihat Gambar 1) ini adalah melakukan investigasi awal kejadian longsor pasca terjadinya longsor di Desa Kalikuning, Kecamatan Tulakan, Kabupaten Pacitan, serta merumuskan rekomendasi terkait kejadian longsor tersebut kepada stakeholder.

\section{TINJ AUAN PUSTAKA}

\subsection{Geologi}

Kondisi geologi wilayah Kabupaten Pacitan dapat dilihat pada Gambar 2. Sebagian besar merupakan batuan gamping miosen yang berupa: kepingan koral, konglomerat batugamping, kalsilutit dan batu gamping hablur (Tml) seperti pada Formasi Punung atau Puger. Selain itu, juga terdapat batuan sedimen miosen yang berupa: pasir tufaan, batu lempung, tufa, serpih, batu lanau, batu pasir dan konglomerat (Tms). Batuan gunungapi oligo-miosen berupa lava, breksi, anglomerat dan tufa, bersusun andesit sampai basal, berlensa, batu gamping hablur, berurat kuarsa, terubah kuat, setempat, termineralkan emas dan tembaga (Tomv).

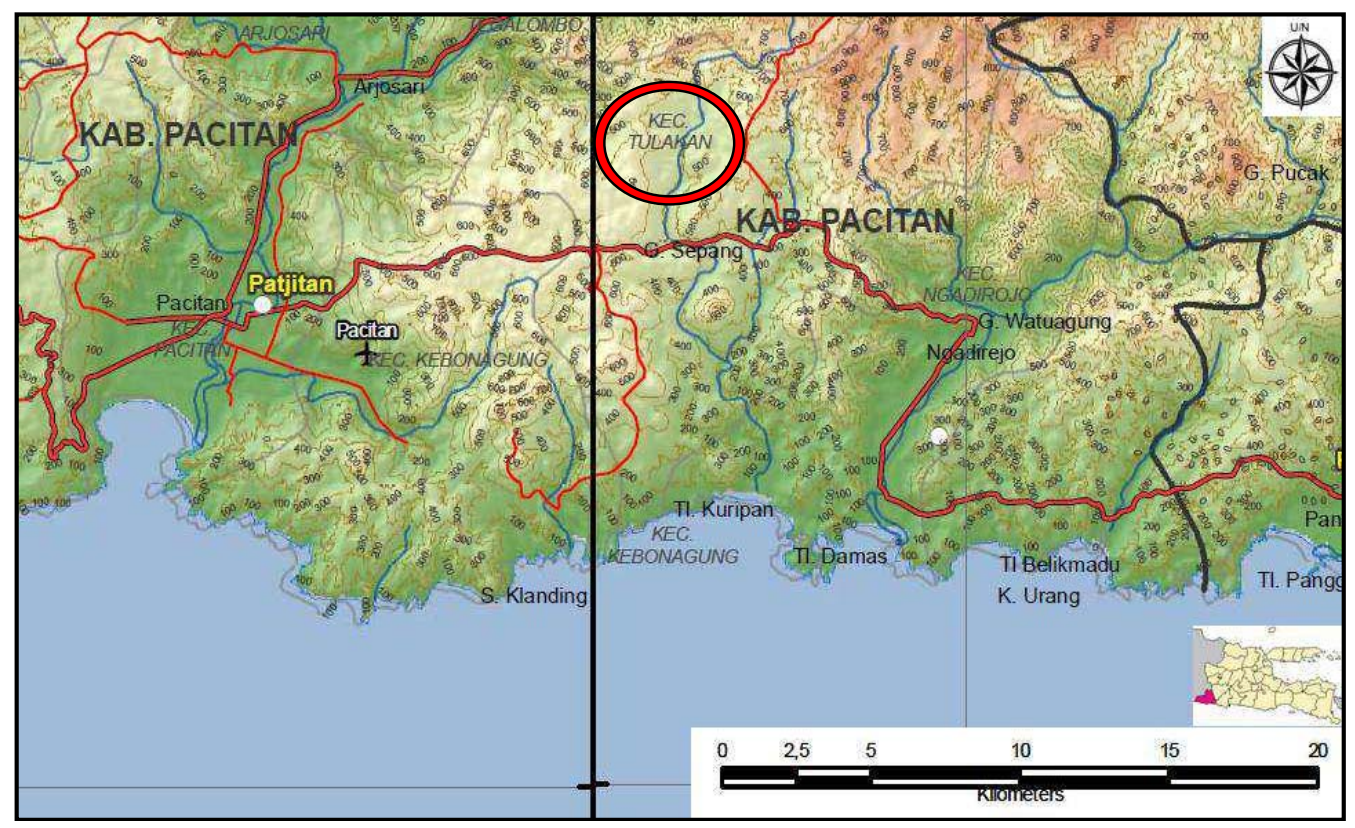

Gambar 1. Lokasi longsor di Kecamatan Tulakan, Kabupaten Pacitan (BNPB, 2010) 


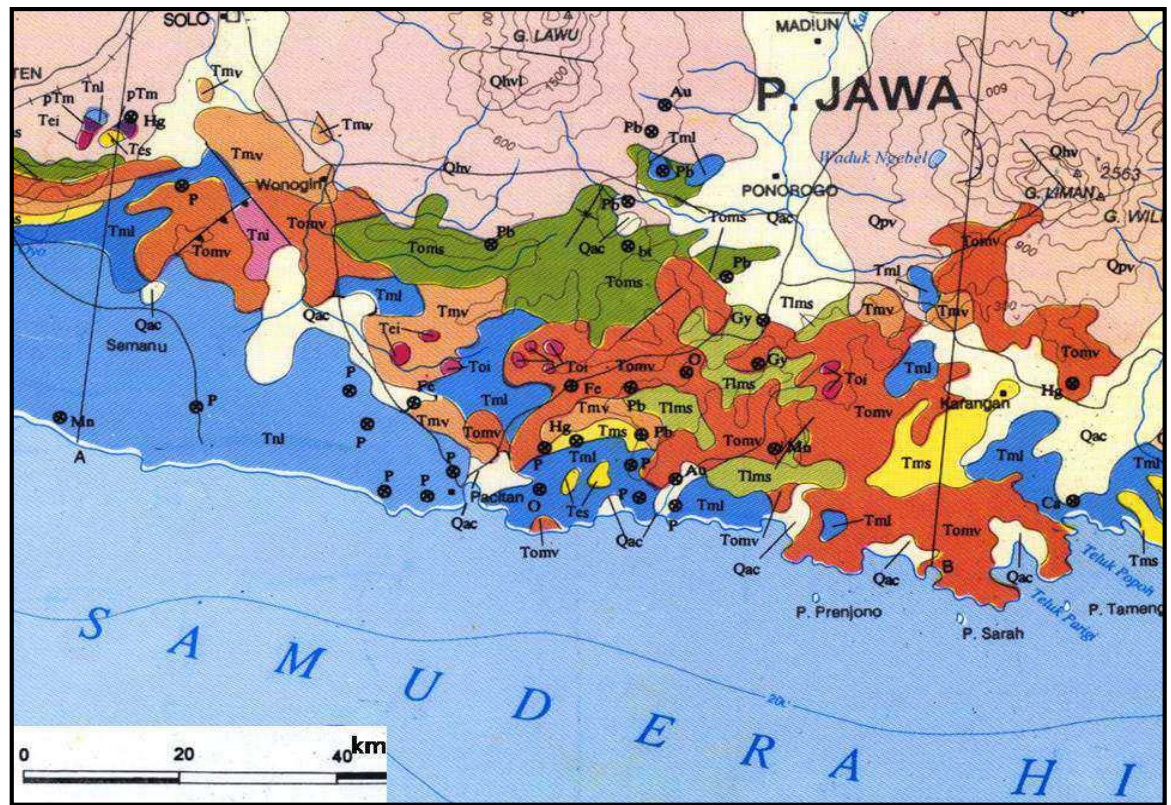

Gambar 2. Peta geologi Pacitan dan sekitarnya (Radman, dkk., 1998).

\subsection{Topografi}

Topografi di wilayah studi, Dusun Sono, berkisar antara 400-600 meter di atas permukaan air laut (Gambar 3). Bentuk potongan melintang lokasi studi, seperti yang ditunjukkan pada Gambar 4.

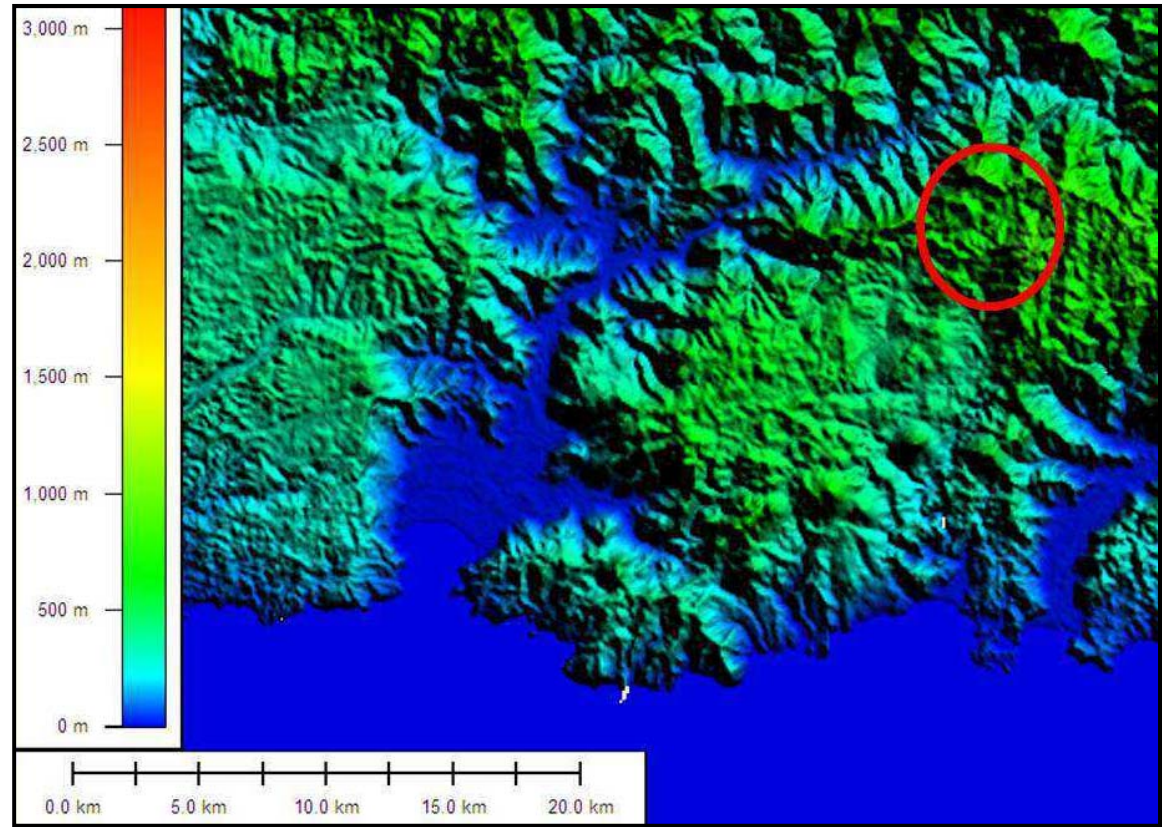

Gambar 3.Peta Topografi Pacitan dan sekitarnya dan lokasi studi, dalam tanda lingkaran. 


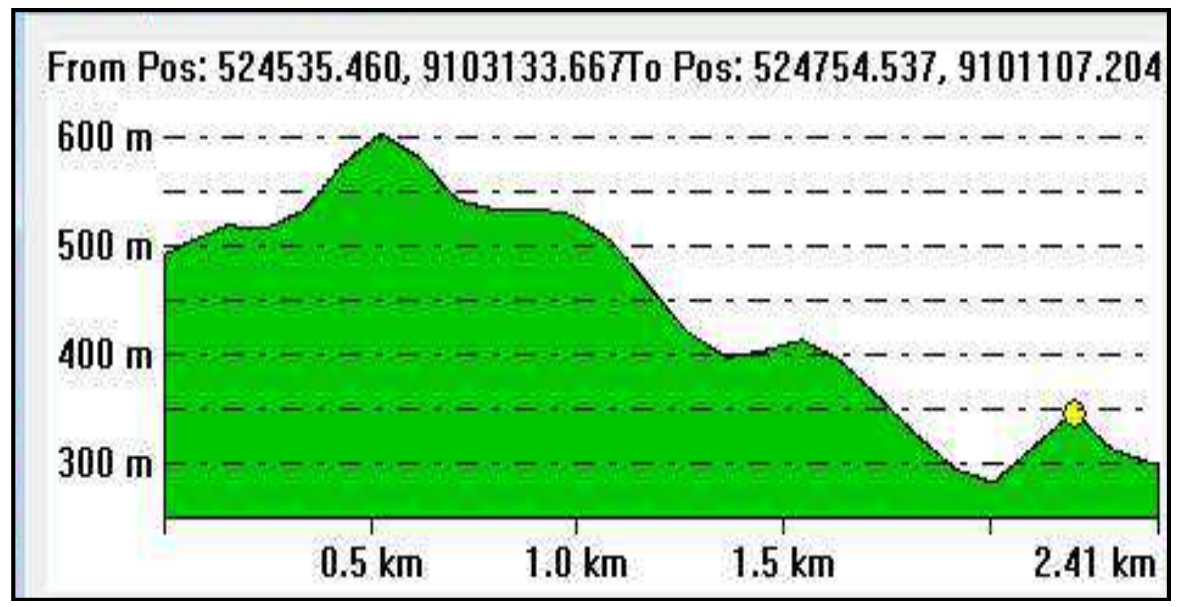

Gambar 4. Prakiraan kemiringan lereng di lokasi studi.

\section{METODE STUDI}

Investigasi lapangan dilakukan dengan cara menelusuri retakan tanah dan amblesannya sebagai gejala awal dari longsoran selanjutnya. Pencatatan lokasi retakan berisi tentang koordinat astronomisnya yang diperoleh dari hasil rekaman Global Potitioning Sistem (GPS). GPS yang digunakan adalah GPS yang bermerk Garmin tipe 76CSx.

Pencatatan koordinat dapat menggunakan dua sistem yaitu sistem koordinatUniversal Transverse Mecator (UTM) atau dengan menggunakan sistem derajat. Untuk laporan investigasi ini, digunakan sistem UTM.Selain posisi astronomis retakan, juga dilakukan pencatatan terkait dengan elevasinya dan arah retakan terhadap arah utara.

Sebagai tahap awal pengolahan data, dilakukan plotting lokasi studi pada google mapper map. Plotting lokasi tersebut berdasarkan data koordinat UTM yang telah direkam sebelumnya seperi pada Gambar 5. Selanjutnya pada Gambar 6 ditunjukkan hasil digitasi lokasi retakan dan amblesan yang berhasil diidentifikasi di lapangan. Metode pencatatan dilakukan dengan cara menyusuri jalan umum, namun apabila terdapat retakan tanah dan amblesan maka diidentifikasi panjang retakan, lebar retakan, kedalaman amblesan, elevasi, dan arah retakan.
Wawancara dengan masyarakat dilakukan untuk menggali dan mendalami informasi terkait kejadian Iongsor. Informasi tersebut meliputi: proses alam sebelum longsor terjadi, pada saat terjadi longsor dan setelah longsor terjadi. Sumber informasi, selain berasal dari masyarakat juga dilakukan wawancara kepada dinas terkait dengan penanganan bencana.

\section{HASIL INVESTIGASI DAN PEMBAHASAN}

4.1. Investigasi Teknis

Berdasarkan hasil investigasi lapangan, maka diperoleh informasi yang berupa: dokumentasi kondisi lapangan, gambar olahan dan deskripsi kejadian. 


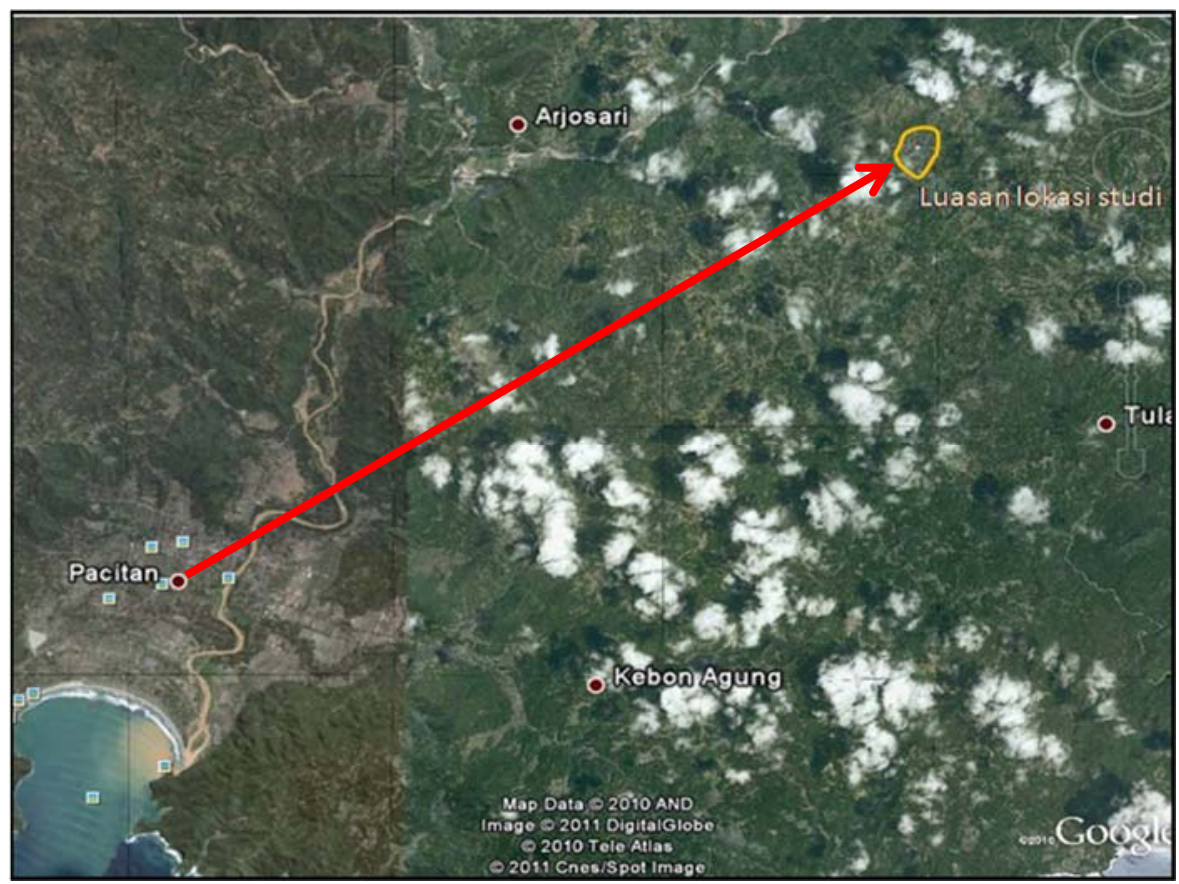

Gambar 5. Posisi lokasi studi dan luasan studi terkait longsor

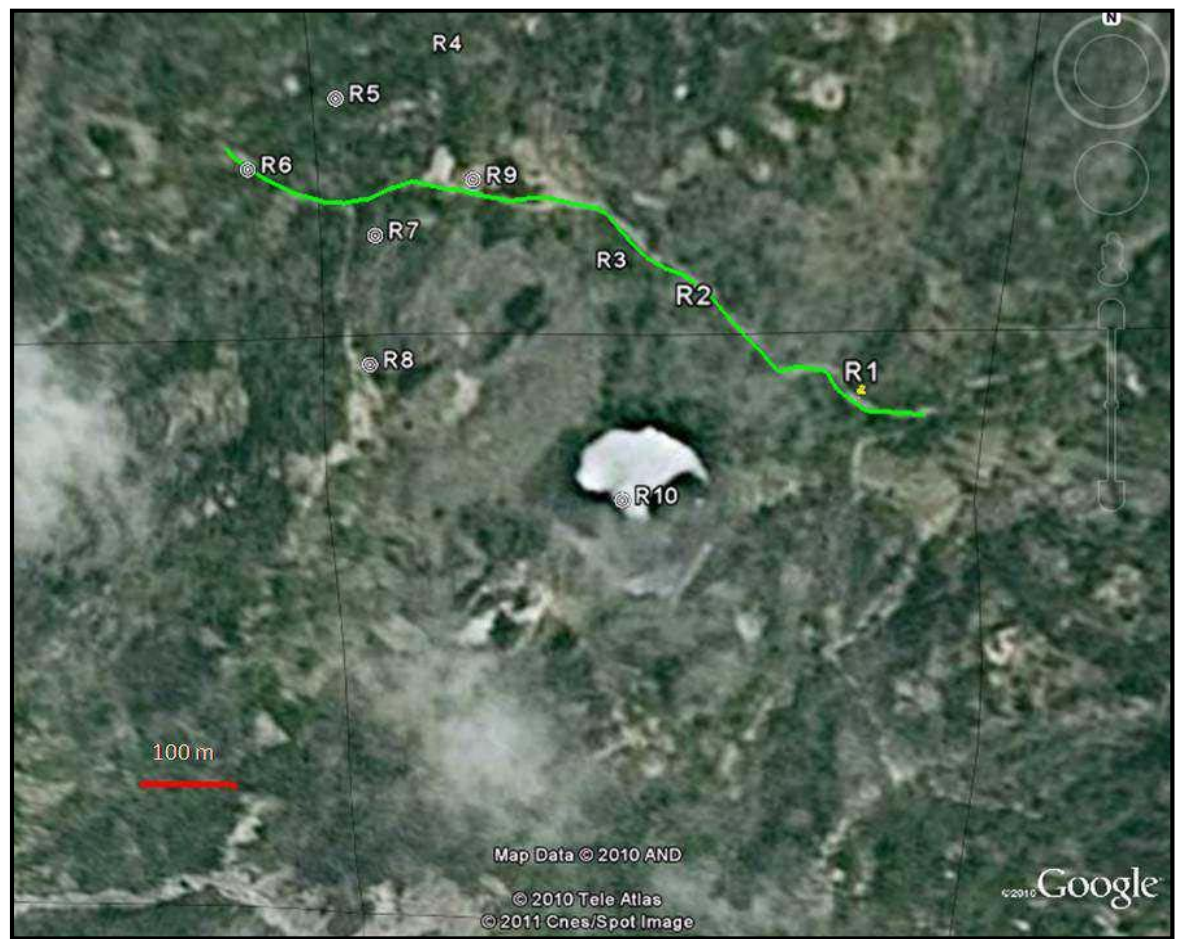

Gambar 6. Sketsa lokasi studi beserta kode fotonya 


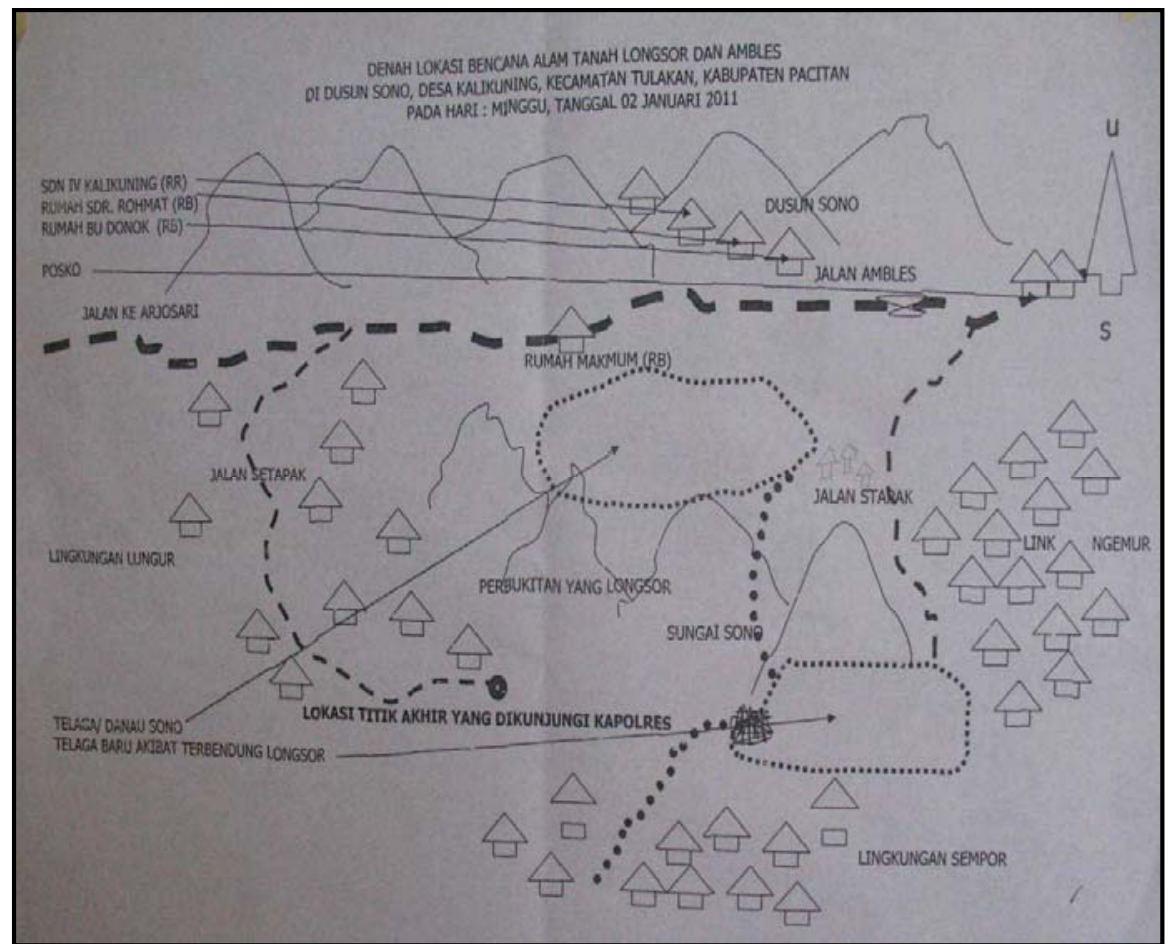

Gambar 7. Sketsa lokasi studi

Gambar 7 menunjukkan peta situasi Dusun Sono, sebagai lokasi utama terjadinya longsor.Berdasarkan informasi dari warga setempat, tanda-tanda retakan telah terjadi pada pertengahan tahun 2010. Tanda-tanda tersebut terlihat antara lain dari tanah yang retak dan memanjang. Pada tanggal 30 Desember 2010 terjadi hujan yang sangat deras.Berdasar naluri, masyarakat memutuskan bahwa pada malam hari mengungsi ke tempat yang dianggap lebih aman. Setelah hujan berselang selama dua hari, maka pada tanggal 2 Januari 2011, terjadilah longsor pada bukit di sisi selatan Telaga Sono.
Longsor di bukit tersebut diiringi dengan suara yang bergemuruh yang terdengar oleh masyarakat sekitar.Akibat longsoran, maka Sungai Sono tertutup oleh material longsor, sehingga sempat terbentuk tampungan kecil selama beberapa hari.Seiring dengan peristiwa longsor, beberapa titik mengalami keretakan dan amblesan sebagaimana terlihat pada Gambar 8. Retakan dan amblesan tersebut berada di permukiman warga, jalan akses dan fasilitas umum lainnya, seperti sekolah. 


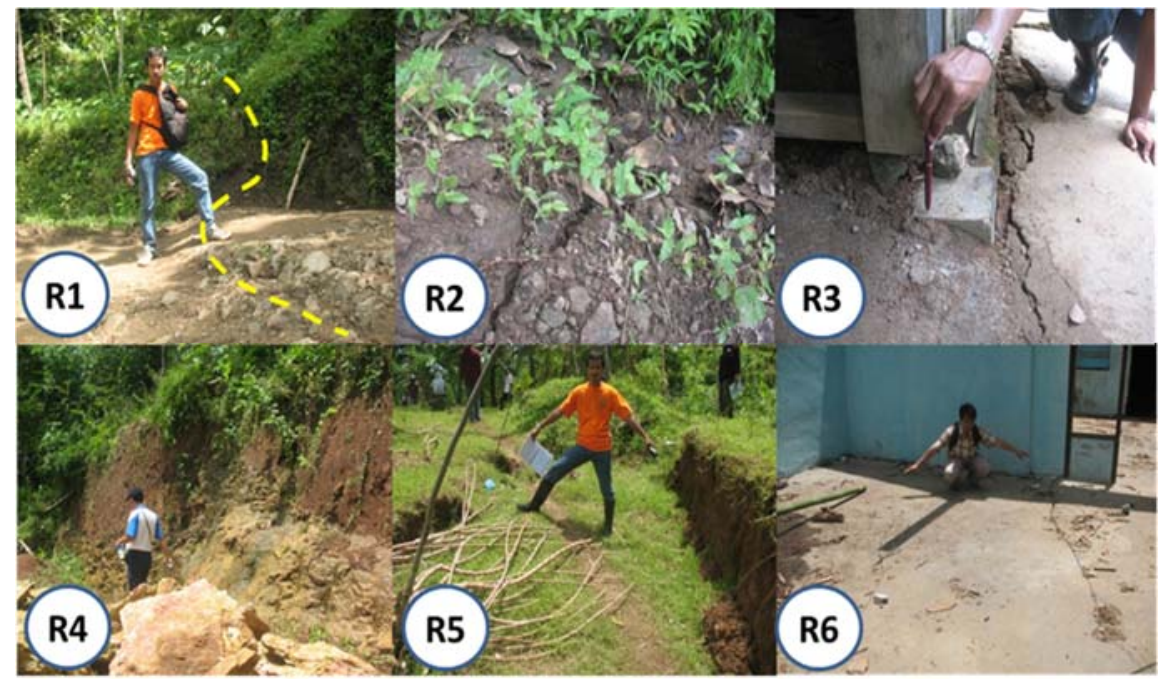

Gambar8. Hasil Investigasi Lapangan dalam Bentuk Visual

Keterangan:

R1. Jalan di sisi kiri telah mengalami amblesan sekitar $30 \mathrm{~cm}$. bagian atas mengalami retakan yang arahnya tegak lurus dengan bukit

R2. Retakan kecil yang terbentuk

R3. Rumah Pak Misran yang mengalami amblesan, sehingga tiang di ujung rumah mengalami gap dengan lantai

R4. Pemotongan lereng untuk dijadikan permukiman.

R5. Dua retakkan memanjang dan searah dengan jarak sekitar 2 meter pada Iantai rumah.

R6. Dua buah retakan tanah dan amblesan sejarak 2 meter.

Berdasarkan hasil analisis, diperkirakan bahwa arah retakan tanah seperti pada Gambar 9 berikut ini. Luasan longsor yang telah terjadi pada tanggal 2 Januari 2011 adalah 12.000 meter persegi (asumsi adalah jarak horisontal pada gambar), sedangkan potensi longsor lanjutan adalah diperkirakanseluas 250.000 meter persegi.

Longsor pada tanggal 2 Januari 2011 tersebut tidak menimbulkan korban jiwa, ataupun korban material secara langsung mengingat lokasi longsor adalah bukit kosong tanpa permukiman. Namun potensi longsor selanjutnya berada di jalan akses, sekolah serta permukiman warga Dusun Sono. Kemungkinan longsor tersebut akan terjadi di RT 1/IX, RT 2/IX serta RT 3/IX yang terletak di dalam "mangkuk" potensi longsor. Jumlah kepala keluarga (KK) dan penduduk masing-masing RT tersebut berturut-turut adalah sebagai berikut $29 \mathrm{KK}$, 183 jiwa; 10 KK, 45 jiwa dan 8 KK, 38 jiwa (sumber : papan informasi posko bantuan). 


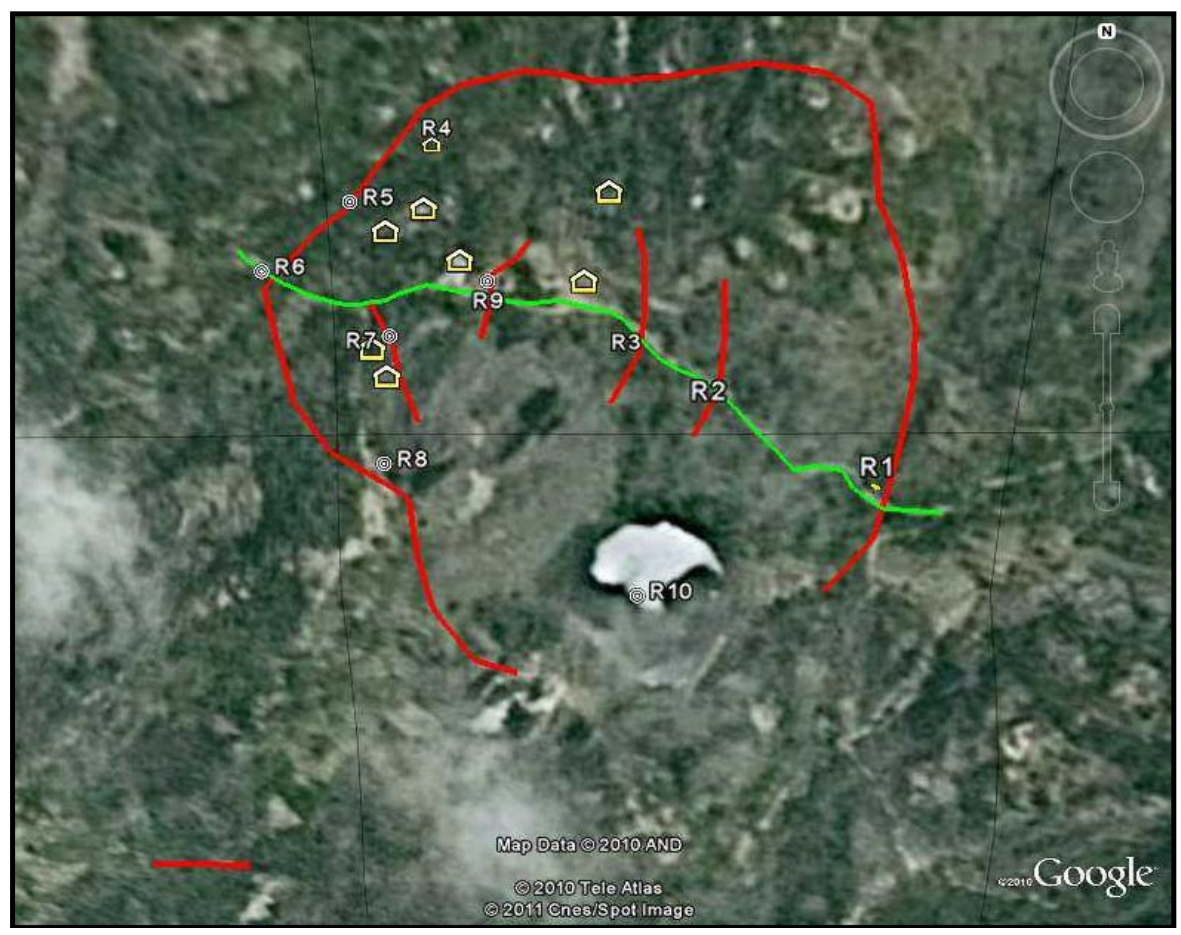

Gambar 9. Prakiraan luasan longsor yang kemungkinan akan terjadi (garis sambung) dan longsor yang telah terjadi (garis putus).

4.2. Adaptasi Masyarakat

Berdasarkan pantauan dan wawancara kepada masyarakat, masyarakat telah mengenali tanda-tanda Iongsor.Informasi tersebut diperoleh dari media informasi. Pengenalan tersebut yaitu dengan memahami tanda-tanda longsor adalah retakan tanah yang memanjang, serta amblesan tanah, juga curah hujan yang tinggi sebagai salah satu pemicunya.
Salah satu bentuk adaptasi adalah dengan cara mengungsi ke tempat yang tidak ada tanda-tanda longsor tiap malam hari, baik ada ataupun tidak ada hujan. Selain itu masyarakat dengan sadar memutuskan membongkar rumah (pindah) ke daerah lain, terutama rumah yang telah mengalami retak-retak, seperti tampak pada Gambar 10 berikut.

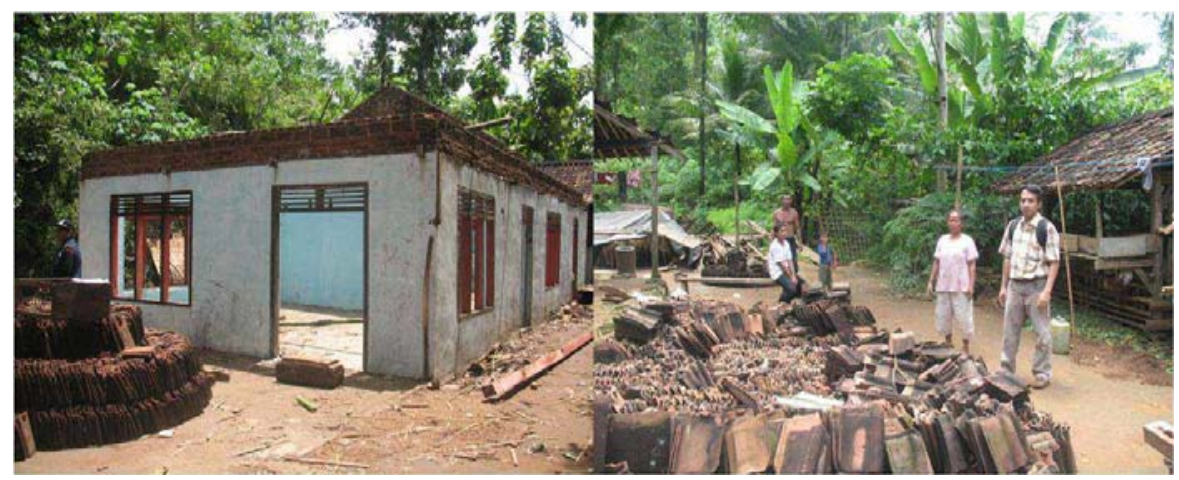

Gambar 10. Rumah warga yang dibongkarakibat adanya retakan tanah di lantai dan penyelamatan bagian rumah hasil bongkaran 


\section{KESIMPULAN DAN REKOMENDASI}

\subsection{Kesimpulan}

Berdasarkan uraian tersebut di atas maka dapat diambil kesimpulan sebagai berikut:

1. Potensi longsor yang lebih besar diperkirakan akan terjadi di Dusun Sono, Desa Kalikuning, Kecamatan Tulakan, Kabupaten Pacitan dengan luasan longsor diperkirakan mencapai 250.000 meter persegi (horisontal).

2. Apabila longsor tersebut terjadi, maka akan menimpa sekitar $47 \mathrm{KK}$ atau 266 jiwa, serta fasilitas umum seperti sekolah dan jalan juga permukiman warga tersebut.

\subsection{Rekomendasi}

Rekomendasi teknis yang dapat disampaikan adalah :

1. Mengevakuasi warga untuk dapat pindah ke lain tempat yang lebih aman.

2. Melarang untuk mengupas lereng untuk dijadikan Iahan permukiman.

3. Edukasi masyarakat terkait potensi bencana dan cara penanganan perlu dilakukan.

\section{DAFTAR PUSTAKA}

[1] Suryolelono K.B. 2002. Bencana Alam Tanah Longsor Perspektif IImu Geologi Teknik. Pidato Pengukuhan Jabatan Guru Besar.

[2] Priyono. 2008. Analisis Morfometri dan Morfostruktur lereng Kejadian Longsor di Kecamatan Banjarmangu, Kabupaten Banjarnegara. Forum Geografi, 22 (1). pp. 72-84. ISSN 0852-0682

[3] Karnawati D. 2002. Pengenalan Daerah Rentan Gerakan Tanah dan Upaya
Mitigasinya, Prosiding Seminar Nasional Mitigasi Bencana Alam. BPPT J akarta.

[4] Tatas dkk. 2011. Laporan Hasil Investigasi Longsor Desa Kalikuning Kecamatan Tulakan Kabupaten Pacitan. PSKB-LPPM ITS Surabaya. 